\title{
Dual Catalyst System Composed by Nickel and Vanadium Complexes Containing Nitrogen Ligands for Ethylene Polymerization
}

\author{
Luciano G. Furlan and Osvaldo L. Casagrande Jr.* \\ Instituto de Química, Universidade Federal do Rio Grande do Sul, Av. Bento Gonçalves, 9500, \\ 91509-900 Porto Alegre - RS, Brazil
}

\begin{abstract}
Blendas de polietileno ramificado/polietileno de alta densidade (BPE/HDPE) foram preparadas usando uma combinação de catalisadores $\left[\mathrm{NiCl}_{2}(\right.$ diimina- $\left.\alpha)\right](\mathbf{1})$ (diimina- $\alpha=1$,4-bis $(2,6$ diisopropilfenila)-acenafeteno) e $\left[\mathrm{Tp}^{\mathrm{Ms} *} \mathrm{VCl}_{2}\left(\mathrm{~N}^{\mathrm{t}} \mathrm{Bu}\right)\right](\mathbf{2})\left(\mathrm{Tp}^{\mathrm{Ms}}{ }^{*}=\right.$ hidridobis(3-mesitilapirazol-1il)(5-mesitilapirazol-1-il)). As reações de polimerização foram realizadas em hexano ou tolueno em três diferentes temperaturas $\left(0,30\right.$ e $\left.50^{\circ} \mathrm{C}\right)$, utilizando várias razões molares de níquel $\left(x_{\mathrm{Ni}}\right)$, na presença de metilaluminoxano (MAO) como cocatalisador. Em todas as temperaturas, as atividades mostraram uma correlação aproximadamente linear $\operatorname{com} x_{\mathrm{Ni}}$, indicando o não aparecimento de um efeito sinérgico entre as espécies de níquel e vanádio. Altas atividades foram obtidas a $0{ }^{\circ} \mathrm{C}$. As temperaturas de fusão $\left(\mathrm{T}_{\mathrm{m}}\right)$ das blendas de polietileno produzidas a $0{ }^{\circ} \mathrm{C}$ diminuem conforme a $x_{\mathrm{Ni}}$ aumenta no meio reacional, indicando uma boa miscibilidade entre as fases de polietileno produzidas por ambos catalisadores. A morfologia da superfície das blendas de BPE/HDPE estudadas por microscopia eletrônica de varredura (MEV) revelou uma baixa miscibilidade entre as fases de PE, principalmente no caso das blendas poliméricas produzidas a alta temperatura $\left(50^{\circ} \mathrm{C}\right)$.
\end{abstract}

Branched polyethylene/high-density polyethylene blends (BPE/HDPE) were prepared using the combined $\left[\mathrm{NiCl}_{2}(\alpha\right.$-diimine $\left.)\right](\mathbf{1})(\alpha$-diimine $=1,4$-bis(2,6-diisopropylphenyl)acenaphthenediimine) and $\left[\mathrm{Tp}^{\mathrm{Ms} *} \mathrm{VCl}_{2}\left(\mathrm{~N}^{\mathrm{t}} \mathrm{Bu}\right)\right](\mathbf{2})\left(\mathrm{Tp}^{\mathrm{Ms}^{*}}=\right.$ hydridobis(3-mesitylpyrazol-1-yl)(5mesitylpyrazol-1-yl) ) catalysts. The polymerization reactions were performed in hexane or toluene at three different polymerization temperatures $\left(0,30\right.$ and $\left.50^{\circ} \mathrm{C}\right)$ and several nickel molar fractions $\left(x_{\mathrm{Ni}}\right)$, using MAO as cocatalyst. At all temperatures, the activities show an approximate linear correlation with $x_{\mathrm{Ni}}$, indicating a non-synergistic effect between the nickel and the vanadium species. Higher activities were found in toluene at $0{ }^{\circ} \mathrm{C}$. The melting temperatures for the polyethylene blends produced at $0{ }^{\circ} \mathrm{C}$ decrease as $x_{\mathrm{Ni}}$ increases in the medium indicating good miscibility between the polyethylene phases made by both catalysts. The surface morphology of the BPE/HDPE blends studied by scanning electron microscopy (SEM) revealed low miscibility between the PE phases mainly in the case of the polymer blends produced at high temperature $\left(50^{\circ} \mathrm{C}\right)$.

Keywords: BPE/HDPE blends, ethylene polymerization, homogeneous binary catalyst system, Nickel and Vanadium catalysts

\section{Introduction}

A large range of polyolefinic materials with interesting properties have been disclosed in the last decades as a result of the development of new classes of olefin polymerization catalysts $^{1}$ as well as of blending existing polymers. ${ }^{2}$ Furthermore, a new approach has been introduced that is based on catalyst systems that combine, in a single reactor, two or more types of catalysts that produce polymers with different and controlled molecular weight averages $(M \mathrm{w})$ and molecular weight distributions (MWD). ${ }^{3}$ This method

*e-mail: osvaldo@iq.ufrgs.br has been successfully used to produce linear low density PE (LLDPE), ${ }^{4}$ branched polyethylenes, ${ }^{5}$ polyethylenes with long chain branches (LCB-PE), ${ }^{6}$ ethylene/1-hexene copolymers, ${ }^{7}$ and polyethylene blends. ${ }^{8}$

In the last few years we have developed homogeneous binary catalyst systems for the production of polyethylene blends, ${ }^{9}$ and LLDPE. ${ }^{10}$ Our studies demonstrated that the variation of polymerization parameters such as solvent, cocatalyst, temperature of polymerization as well as metal mole fraction strongly influences the activity and polymer properties. Particularly, for the binary catalytic system composed of $\left[\mathrm{NiCl}_{2}(\alpha\right.$-diimine $\left.)\right]$ ( $\alpha$-diimine $=1,4$-bis $(2,6$ diisopropylphenyl)-acenaphthenediimine $) /\left[\mathrm{Tp}^{\mathrm{Ms}^{*}} \mathrm{TiCl}_{3}\right]$ 
$\left(\mathrm{Tp}^{\mathrm{Ms} *}=\right.$ hydridobis(3-mesitylpyrazol-1-yl)(5-mesitylpyrazol-1-yl) $)^{9}$ we have found evidence of synergistic effects between the two catalytic species.

Herein, we describe the use of $\left[\mathrm{NiCl}_{2}(\alpha\right.$-diimine $\left.)\right](\mathbf{1})$ ( $\alpha$-diimine $=1,4$-bis(2,6-diisopropylphenyl)-acenaphthenediimine) and $\left[\mathrm{Tp}^{\mathrm{Ms} *} \mathrm{VCl}_{2}\left(\mathrm{~N}^{\mathrm{t}} \mathrm{Bu}\right)\right]$ (2) $\left[\mathrm{Tp}^{\mathrm{Ms} *}=\right.$ hydridobis(3-mesitylpyrazol-1-yl)(5-mesitylpyrazol-1-yl)] in the ethylene polymerization toward the production of polymer blends. Studies related to the effect of polymerization temperature, solvent, and nickel mole fraction $\left(x_{\mathrm{Ni}}\right)^{11}$ on the activity and polymer properties are presented.

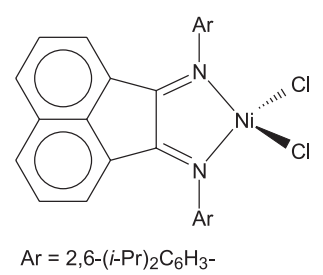

1

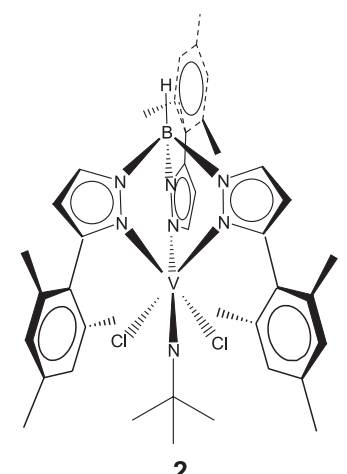

2

\section{Experimental}

\section{Materials}

The compounds $\left[\mathrm{NiCl}_{2}(\alpha\right.$-diimine $\left.)\right](\mathbf{1})(\alpha$-diimine $=$ 1,4-bis(2,6-diisopropylphenyl)-acenaphthenediimine), ${ }^{12}$ and $\left[\mathrm{Tp}^{\mathrm{Ms}^{*}} \mathrm{VCl}_{2}(\mathrm{~N} \mathrm{Bu})\right](\mathbf{2})\left(\mathrm{Tp}^{\mathrm{Ms}}{ }^{*}=\operatorname{hydridobis}(3-\right.$ mesitylpyrazol-1-yl)(5-mesitylpyrazol-1-yl)), ${ }^{13}$ were synthesized following procedures described in the literature. Ethylene (polymer grade, White Martins) and argon were deoxygenated and dried by passage through columns of BTS (BASF) and activated molecular sieves (3 $\AA$ ) prior to use. MAO (Witco, 5.21 wt. \% toluene solution) was used as received. Toluene and hexane were refluxed and distilled over sodium benzophenone ketyl. Solvents were stored under argon or vacuum prior to use.

\section{Polymerization procedures}

All polymerization reactions were performed in a $1.0 \mathrm{~L}$ Pyrex glass reactor connected to a constant temperature circulator and equipped with mechanical stirring and inlets for argon and ethylene. The reactor was rinsed with $300 \mathrm{~mL}$ of a $0.04 \mathrm{~mol} \mathrm{~L}^{-1} \mathrm{Al}\left({ }^{i} \mathrm{Bu}\right)_{3}$ solution in hexane prior to use. Under argon atmosphere were introduced sequentially the proper amounts of solvent (toluene or hexane) and MAO solution, and then the system was saturated with ethylene. After complete saturation with ethylene at atmospheric pressure and thermal equilibration of the system, the polymerization reactions were started by adding solutions of $\mathbf{1}$ and/or $\mathbf{2}$ to the reactor. The total volume of the reaction mixtures was $300 \mathrm{~mL}$ for all polymerizations. The polymerization reaction was stopped by the addition of 1 $\mathrm{mL}$ of methanol. The polymer was washed with acidic ethanol, then water and ethanol, and dried in a vacuum oven at $60^{\circ} \mathrm{C}$ for $12 \mathrm{~h}$. On the basis of the results of multiple runs, we estimate the accuracy of the activities to $\pm 8 \%$.

\section{Film preparation}

Differential scanning calorimetry (DSC) data and morphology studies were evaluated from films. Polyethylene films were prepared in a Carver press Monarch series, model 3710 ASTM. The polymers were pre-heated for $2 \mathrm{~min}$ at 160 ${ }^{\circ} \mathrm{C}$ between the press plates without pressure and then pressed for $2 \mathrm{~min}$ at $3 \mathrm{kgf} \mathrm{cm}^{-2}$ at the same temperature. After this time, the pressure was released and the films were controlcooled down to room temperature at the cooling rate of 10 or $18{ }^{\circ} \mathrm{C} \mathrm{min}-1$, or quenched in water-ice bath or liquid nitrogen. The film thickness was $0.15 \mathrm{~mm} \pm 0.02$.

\section{Polymer characterization}

Polymer melting temperatures $\left(\mathrm{T}_{\mathrm{m}}\right)$ were determined on a Thermal Analysis Instruments DSC-2010 calibrated with Indium, using a heating rate of $10^{\circ} \mathrm{C} \mathrm{min}^{-1}$ in the temperature range $40-180{ }^{\circ} \mathrm{C}$ and cooling to $40{ }^{\circ} \mathrm{C}$ at $10{ }^{\circ} \mathrm{C} \mathrm{min}{ }^{-1}$. The heating cycle was performed twice, and only the results of the second cycle are reported. Melt flow indexes (MFI) were determined at $190{ }^{\circ} \mathrm{C}$ using a $21.6 \mathrm{~kg}$ standard charge.

\section{Blend morphology}

The morphology was studied by using a Scanning Electron Microscope (JEOL JSM 5800). Samples were fractured under liquid nitrogen and the fractured surfaces were coated with gold.

\section{Results and Discussion}

Influence of $x_{N i}$, temperature, and solvent on activity.

The ethylene polymerization reactions were carried out using methylaluminoxane-activated $\left[\mathrm{NiCl}_{2}(\alpha\right.$-diimine $\left.)\right](\mathbf{1})$ and $\left[\mathrm{Tp}^{\mathrm{Ms} *} \mathrm{VCl}_{2}\left(\mathrm{~N}^{\mathrm{t}} \mathrm{Bu}\right)\right](\mathbf{2})$ in hexane/toluene at 0,30 , and $50{ }^{\circ} \mathrm{C}$. Tables 1 and 2 show the results of polymerization runs by varying the nickel loading molar fraction $\left(x_{\mathrm{Ni}}\right)$.

The ethylene polymerization reactions performed employing $\mathbf{1}$ and $\mathbf{2}$ separately showed that the catalytic 
system 1/MAO exhibited higher activities than 2/MAO for all temperatures and solvents employed in the polymerization runs as can be seen in Figures 1 and 2. The catalytic system $\mathbf{1} / \mathrm{MAO}$ reached a maximum activity in toluene at $0{ }^{\circ} \mathrm{C}\left(2248 \mathrm{Kg}\right.$ of $\mathrm{PE} \mathrm{mol}\left[\mathrm{Ni}^{-1} \mathrm{~h}^{-1}\right.$, entry 20) while a highest activity for system $2 / \mathrm{MAO}$ was obtained in hexane at $30^{\circ} \mathrm{C}\left(456 \mathrm{Kg}\right.$ of PE mol[V] ${ }^{-1} \mathrm{~h}^{-1}$, entry 6$)$.

Comparing the performance of both catalytic systems it was observed that the nickel catalyst was more sensitive to temperature, than the vanadium catalyst decreasing the activity with increasing polymerization temperature. Furthermore, the difference between the activities obtained for the systems $1 / \mathrm{MAO}$ and $2 / \mathrm{MAO}$ decreases as the polymerization temperature increases, this effect being more pronounced in hexane. For instance, at $50{ }^{\circ} \mathrm{C}$ this activity difference was 1.2 fold and reaches 3.9 fold at 0 ${ }^{\circ} \mathrm{C}$ (compare entries 1 and 5, and 11 and 15).

Polymerization runs carried out when varying $x_{\mathrm{Ni}}$ and temperature, with constant amount of MAO, showed that the activities are strongly dependent on these parameters as can be seen in Figures 1 and 2. At low temperature $\left(0^{\circ} \mathrm{C}\right)$ apparently the solvent does not promote any significant influence on the activity. In that case, the activities increase linearly with $x_{\mathrm{Ni}}$ indicating that each catalyst precursor work independently. At higher polymerization temperatures (30 and $50{ }^{\circ} \mathrm{C}$ ) the influence of the solvent on the activity is

Table 1. Ethylene polymerization using homogeneous binary catalyst system composed of $\left[\mathrm{NiCl}_{2}(\alpha-\operatorname{diimine})\right](\mathbf{1})$ and $\left[\mathrm{Tp}^{\mathrm{Ms} *} \mathrm{VCl}\left(\mathrm{N}_{2} \mathrm{Bu}\right)\right](\mathbf{2})$ in hexane under atmospheric ethylene pressure ${ }^{a}$

\begin{tabular}{|c|c|c|c|c|c|c|c|}
\hline Entry & $x_{\mathrm{Ni}}^{\mathrm{b}}$ & $\mathrm{T}\left({ }^{\circ} \mathrm{C}\right)$ & Polymer yield(g) & Activity $^{\mathrm{c}}$ & $\mathrm{T}_{\mathrm{m}}\left({ }^{\circ} \mathrm{C}\right)$ & $\chi(\%)$ & $\mathrm{MFI}^{\mathrm{d}}(\mathrm{g} / 10 \mathrm{~min})$ \\
\hline 1 & 0.00 & 0 & 1.07 & 428 & 144 & 20 & $<0.001$ \\
\hline 2 & 0.25 & 0 & 1.84 & 736 & 142 & 18 & $<0.001$ \\
\hline 3 & 0.50 & 0 & 2.22 & 888 & 135 & 17 & 0.010 \\
\hline 4 & 0.75 & 0 & 2.85 & 1140 & 124 & 16 & 0.010 \\
\hline 5 & 1.00 & 0 & 4.20 & 1680 & 121 & 14 & 0.020 \\
\hline 6 & 0.00 & 30 & 1.14 & 456 & 144 & 23 & $<0.001$ \\
\hline 7 & 0.25 & 30 & 0.72 & 288 & 139 & 14 & 0.140 \\
\hline 8 & 0.50 & 30 & 0.47 & 188 & 138 & 5 & 1.790 \\
\hline 9 & 0.75 & 30 & 0.84 & 336 & 135 & 3 & 1.900 \\
\hline 10 & 1.00 & 30 & 2.06 & 824 & - & - & 13.10 \\
\hline 11 & 0.00 & 50 & 1.07 & 428 & 143 & 29 & $<0.001$ \\
\hline 12 & 0.25 & 50 & 0.90 & 360 & 142 & 20 & $<0.001$ \\
\hline \multirow[t]{2}{*}{13} & $0.50^{\mathrm{e}}$ & 50 & 0.10 & 204 & 142 & 25 & $<0.001$ \\
\hline & & & 0.41 & & - & - & 142.00 \\
\hline \multirow[t]{2}{*}{14} & $0.75^{\mathrm{e}}$ & 50 & 0.09 & 180 & 139 & 17 & 0.180 \\
\hline & & & 0.36 & & - & - & 147.00 \\
\hline 15 & 1.00 & 50 & 1.37 & 548 & _- & - & 156.00 \\
\hline
\end{tabular}

a Polymerization conditions: Glass Reactor $(1 \mathrm{~L})$; hexane $=300 \mathrm{~mL} .[\mathrm{Al}] /[\mathrm{M}]=500 ; \mathrm{MAO}$ as activator; ${ }^{\mathrm{b}} x_{\mathrm{Ni}}=[\mathrm{Ni}] /([\mathrm{Ni}]+[\mathrm{V}]) ;{ }^{\mathrm{c}} \mathrm{kg}$ of $\mathrm{PE} \mathrm{mol}[\mathrm{M}]^{-1} \mathrm{~h}^{-1}$; ${ }^{\mathrm{d}}$ Melt flow indexes (MFI) were determined at $190^{\circ} \mathrm{C}$ using a $21.6 \mathrm{~kg}$ standard charge; ${ }^{\mathrm{T}}$ The reaction showed spontaneous separation of the PE phases.

Table 2. Ethylene polymerization using homogeneous binary catalyst system composed of $\left[\mathrm{NiCl}_{2}(\alpha\right.$-diimine $\left.)\right](\mathbf{1})$ and $\left[\mathrm{Tp}^{\mathrm{Ms} *} \mathrm{VCl}\left(\mathrm{N}^{\prime} \mathrm{Bu}\right)\right](\mathbf{2})$ in toluene under atmospheric ethylene pressure ${ }^{\mathrm{a}}$

\begin{tabular}{|c|c|c|c|c|c|c|c|}
\hline Entry & $\mathrm{x}_{\mathrm{Ni}}{ }^{\mathrm{b}}$ & $\mathrm{T}\left({ }^{\circ} \mathrm{C}\right)$ & Polymer yield(g) & Activity $^{\mathrm{c}}$ & $\mathrm{T}_{\mathrm{m}}\left({ }^{\circ} \mathrm{C}\right)$ & $\chi(\%)$ & $\operatorname{MFI}^{\mathrm{d}}(\mathrm{g} / 10 \mathrm{~min})$ \\
\hline 16 & 0.00 & 0 & 0.44 & 176 & 146 & 27 & $<0.001$ \\
\hline 17 & 0.25 & 0 & 1.99 & 796 & 141 & 16 & $<0.001$ \\
\hline 18 & 0.50 & 0 & 2.53 & 1012 & 126 & 12 & $<0.001$ \\
\hline 19 & 0.75 & 0 & 5.23 & 2092 & 122 & 12 & $<0.001$ \\
\hline 20 & 1.00 & 0 & 5.62 & 2248 & 118 & 15 & $<0.001$ \\
\hline 21 & 0.00 & 30 & 0.85 & 340 & 143 & 19 & $<0.001$ \\
\hline 22 & 0.25 & 30 & 1.04 & 416 & 141 & 19 & $<0.001$ \\
\hline 23 & 0.50 & 30 & 1.48 & 592 & 135 & 2 & 0.560 \\
\hline 24 & 0.75 & 30 & 2.23 & 892 & 137 & 4 & 1.820 \\
\hline 25 & 1.00 & 30 & 3.73 & 1492 & - & - & 0.420 \\
\hline 26 & 0.00 & 50 & 0.58 & 232 & 143 & 19 & $<0.001$ \\
\hline 27 & 0.25 & 50 & 0.41 & 164 & 139 & 13 & $<0.001$ \\
\hline 28 & 0.50 & 50 & 1.09 & 436 & 137 & 1 & 19.16 \\
\hline 29 & 0.75 & 50 & 1.36 & 544 & 138 & 1 & 27.96 \\
\hline 30 & 1.00 & 50 & 1.72 & 688 & - & - & 95.10 \\
\hline
\end{tabular}

${ }^{\mathrm{a}}$ Polymerization conditions: Glass Reactor $(1 \mathrm{~L})$; toluene $=300 \mathrm{~mL} .[\mathrm{Al}] /[\mathrm{M}]=500 ; \mathrm{MAO}$ as activator; ${ }^{\mathrm{b}} x_{\mathrm{Ni}}=[\mathrm{Ni}] /([\mathrm{Ni}]+[\mathrm{V}]) ;{ }^{\mathrm{c}} \mathrm{kg}$ of PE$\cdot \mathrm{mol}[\mathrm{M}]^{-1} \mathrm{~h}^{-1} ;{ }^{\mathrm{d}} \mathrm{Melt}$ flow indexes (MFI) were determined at $190{ }^{\circ} \mathrm{C}$ using a $21.6 \mathrm{~kg}$ standard charge. 
more clearly presented. For the polymerization reactions performed in toluene the dependence of the activity with respect to the $x_{\mathrm{Ni}}$ was roughly linear.

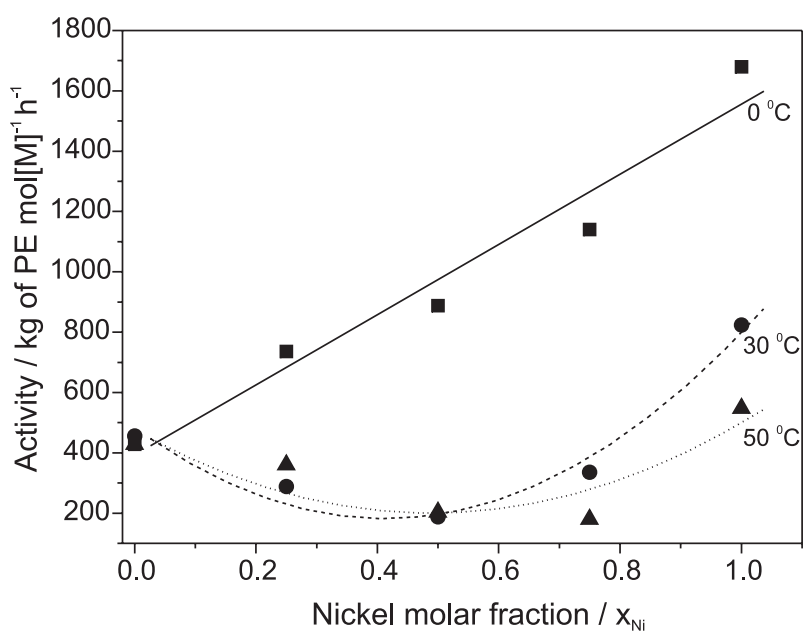

Figure 1. Influence of the polymerization temperature on the activity varying $x_{\mathrm{Ni}}$ for the polymerization reactions performed in hexane.

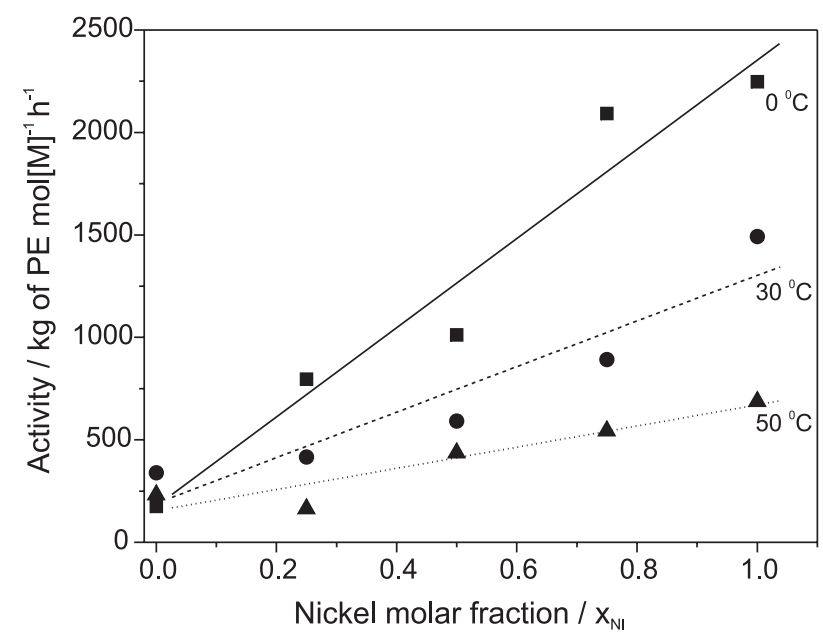

Figure 2. Influence of the polymerization temperature on the activity varying $x_{\mathrm{Ni}}$ for the polymerization reactions performed in toluene.

On the other hand, the use of hexane instead toluene determined a clearly non-linear correlation between the nickel molar fraction $\left(x_{\mathrm{Ni}}=0.25,0.50\right.$ and 0.75$)$ and the activity, suggesting that the combination of $\mathbf{1}$ and $\mathbf{2}$ in this solvent can be promoting a partial deactivation of these catalyst precursors. For instance, the activities found for $x_{\mathrm{Ni}}=0.50\left(30{ }^{\circ} \mathrm{C}, 188 \mathrm{~kg}\right.$ of $\mathrm{PE} \mathrm{mol}[\mathrm{M}]^{-1} \mathrm{~h}^{-1} ; 50{ }^{\circ} \mathrm{C}, 204 \mathrm{~kg}$ of $\left.\mathrm{PE} \mathrm{mol}[\mathrm{M}]^{-1} \mathrm{~h}^{-1}\right)$ are 3.4 and 2.4 times respectively lower than the predicted ones $\left(30^{\circ} \mathrm{C}, 640 \mathrm{~kg} \text { of PE mol[M }\right]^{-1} \mathrm{~h}^{-1}$; $50{ }^{\circ} \mathrm{C}, 488 \mathrm{~kg}$ of $\left.\mathrm{PE} \mathrm{mol}[\mathrm{M}]^{-1} \mathrm{~h}^{-1}\right) .^{14}$
Influence of $x_{N i}$ and polymerization temperature on the polymer properties

The influences of $x_{\mathrm{Ni}}$, solvent and polymerization temperature on polyethylene microstructure have been evaluated by means of differential scanning calorimetry (DSC), and melt flow index (MFI). The results are summarized in Tables 1 and 2.

The melting temperature $\left(\mathrm{T}_{\mathrm{m}}\right)$ of the polymers produced by $\mathbf{1}$ or $\mathbf{2}$ is not extensively affected by changing the solvent. As expected, the branched polyethylenes (BPE) produced by $\mathbf{1}\left(x_{\mathrm{Ni}}=1.00\right)$ have $\mathrm{T}_{\mathrm{m}}$ of $118^{\circ} \mathrm{C}$ (toluene) and $121{ }^{\circ} \mathrm{C}$ (hexane) while the high-density polyethylenes (HDPE) produced by $2\left(x_{\mathrm{Ni}}=0.00\right)$ show $\mathrm{T}_{\mathrm{m}}$ around $145^{\circ} \mathrm{C}$.

In contrast to the thermal behavior of the PE blends produced at $0{ }^{\circ} \mathrm{C}$ using the homogeneous binary catalyst system $\left[\mathrm{NiCl}_{2}(\alpha\right.$-diimina $\left.)\right] /\left[\mathrm{rac} \text {-etilenebis }\left(\mathrm{IndH}_{4}\right) \mathrm{ZrCl}_{2}\right]^{9}$, broad single melting and crystallization peaks were observed in the PE blends produced by 1/2/MAO catalyst system, indicating good miscibility between the branched and high-densisty PE phases (Figures 3 and 4). It is significant to note that the $T_{m}$ is strongly influenced by the nickel molar fraction whatever the solvent used in the polymerization reaction. For instance, the $T_{m}$ values for the polyethylene blends produced in hexane varied from $122{ }^{\circ} \mathrm{C}\left(x_{\mathrm{Ni}}=0.75\right)$ to $141{ }^{\circ} \mathrm{C}\left(x_{\mathrm{Ni}}=0.25\right)$.

At higher polymerization temperatures $\left(30\right.$ and $\left.50{ }^{\circ} \mathrm{C}\right)$ only a slight decrease of $\mathrm{T}_{\mathrm{m}}$ was observed. At these temperatures, the polyethylenes formed by $\mathbf{1}$ are totally amorphous due to the higher branch content ${ }^{15}$ and apparently they do not interfere in the crystallization process of the high-density polyethylenes due to a higher level of phase segregation. This phenomenon could be better visualized in the polymerization reactions carried out in hexane at $50{ }^{\circ} \mathrm{C}$ where two polymers (BPE and HDPE) separated spontaneously and thus allowed the analysis of both phases (entries 13 and 14).

A comparition of the DSC results of the polymer samples produced in toluene at 0,30 , and $50{ }^{\circ} \mathrm{C}$ (Figure 5), shows higher dependence of the $\mathrm{T}_{\mathrm{m}}$ values with respect to the $x_{\mathrm{Ni}}$ for the polyethylene blends produced at $0{ }^{\circ} \mathrm{C}$ than at 30 or $50{ }^{\circ} \mathrm{C}$. $\mathrm{T}_{\mathrm{m}}$ values decrease as the polymerization temperature increases indicating that at lower polymerization temperatures the miscibility between the PE phases is more effective. It is worth noting that nickel- $\alpha$-diimine complexes show ability to promote the displacement of the metal along the growing polymer chain so-called chain walking mechanism. ${ }^{16}$ This process determines the number of branches in the polymer backbone. Therefore the extent of branching in the PE is sensitive to polymerization temperature, decreasing with decreasing polymerization temperature. At 0 


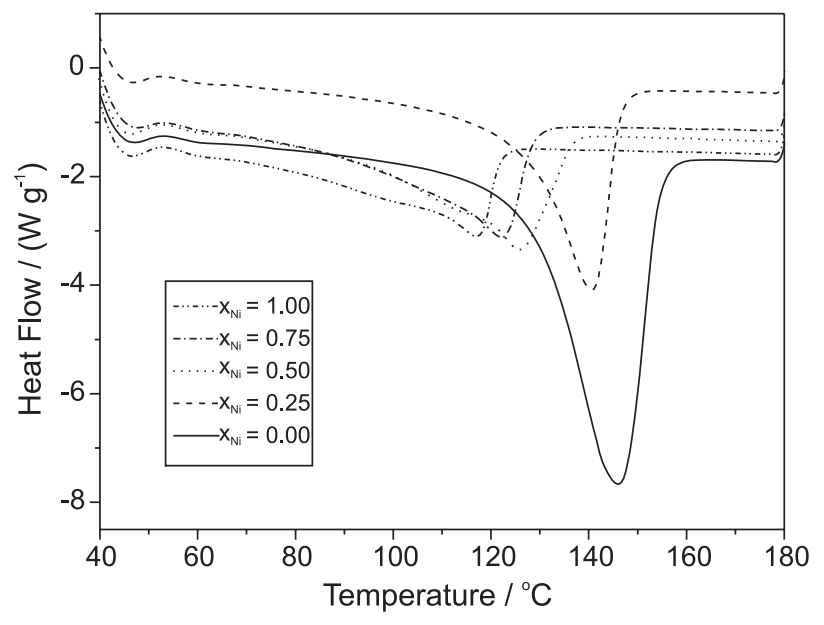

Figure 3. DSC curves of the PE blends produced in toluene at $0{ }^{\circ} \mathrm{C}$.

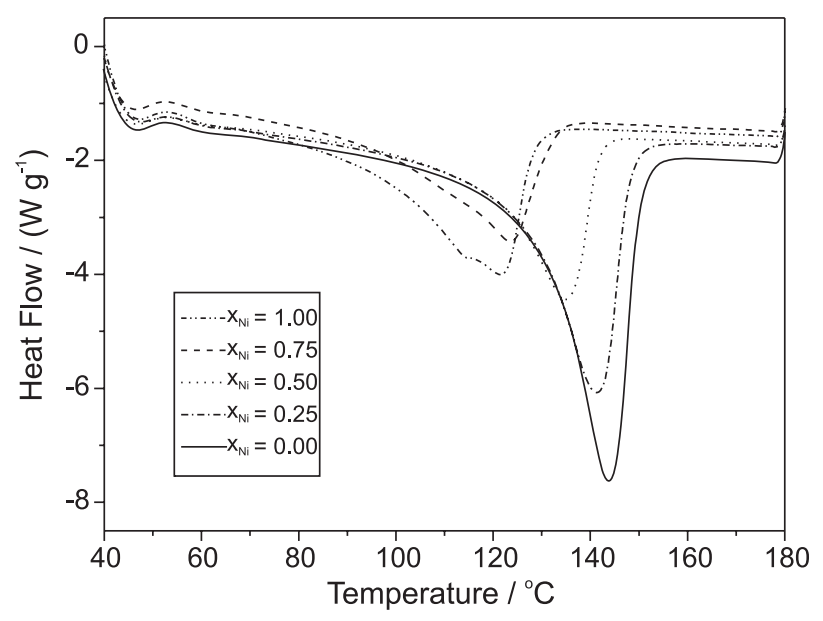

Figure 4. DSC curves of the PE blends produced in hexane at $0{ }^{\circ} \mathrm{C}$.

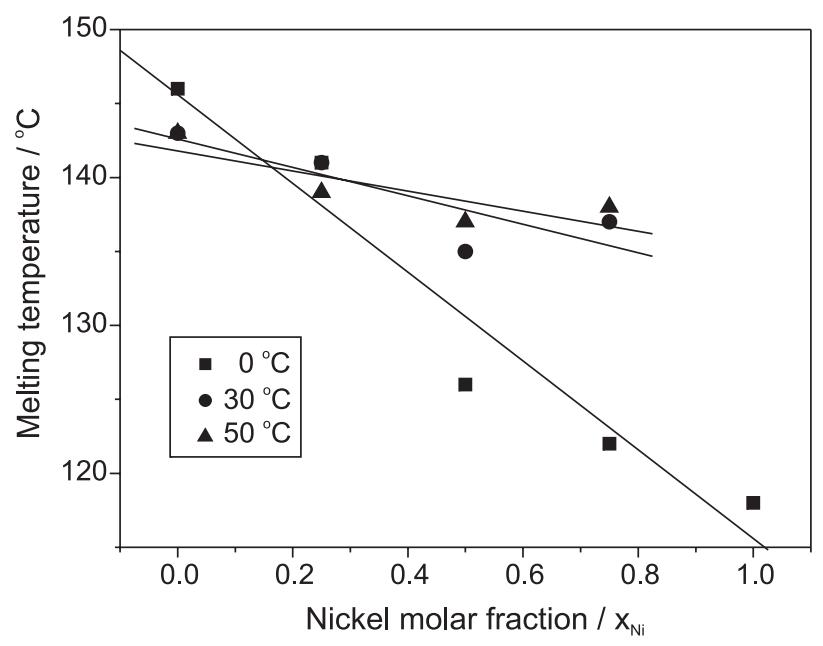

Figure 5. Dependence of the melting temperature $\left(\mathrm{T}_{\mathrm{m}}\right)$ on $x_{\mathrm{Ni}}$ for polymerization of ethylene in toluene.
${ }^{\circ} \mathrm{C}, \mathbf{1}$ produces $\mathrm{PE}$ with lower degree of branching and thus, its miscibility with the PE produced by $\mathbf{2}$ is more pronounced.

As expected, the polyethylenes produced by $\mathbf{1}$ showed higher melt flow indexes (MFI) compared to those obtained using $\mathbf{2}$, since catalyst $\mathbf{2}$ produces ultra-high molecular weight PE. ${ }^{13}$ The MFI data for the polymer blends produced at $0{ }^{\circ} \mathrm{C}$ indicate the formation of polymer with high molecular weight. These very low MFI values can be associated to the production of high molecular weight polyethylene by $\mathbf{1}$ at this polymerization temperature. ${ }^{17,9}$ In general, at higher polymerization temperatures $\left(30\right.$ and $50^{\circ} \mathrm{C}$ ) the MFI values increase as the $\mathrm{x}_{\mathrm{Ni}}$ increases in the medium, this behavior being attributed to the formation of more branched and lower molecular weight polyethylenes produced mainly by $\mathbf{1} .{ }^{15}$

\section{Morphology of the PE blends}

The morphology of the polymer blends was investigated using scanning electron microscopy (SEM). SEM micrographs made on cryo-fractured surfaces of the polyethylene blend samples produced at 30 and $50{ }^{\circ} \mathrm{C}$ using $x_{\mathrm{Ni}}=0.25$ are shown in Figures 6 and 7. The SEM micrograph of the blend samples produced at $30^{\circ} \mathrm{C}$ showed two phase components (Figure 6a) well dispersed. Increasing the polymerization temperature $\left(50{ }^{\circ} \mathrm{C}\right)$ there occured the production of a BPE/HDPE blend which also shows a double morphology, but in this case the presence of very small particles of BPE dispersed in the HDPE matrix was observed (Figure 7a). In order to evaluate the distribution of the PE phases in the matrix, cryo-fractured surfaces were etched with hot $o$-xylene and studied by SEM. Figure $6 \mathrm{~b}$ shows the formation of large holes and defects distributed on HDPE matrix as a consequence of the extraction of the branched PE produced by $\mathbf{1}$. The nonuniform distribution of these holes and defects on the HDPE surface indicates the high incompatibility degree of these two phase components, considering mainly the large difference between the molecular weight of the PE produced by $\mathbf{1}$ and that produced by $\mathbf{2}$, which is responsible for the formation of ultra-high molecular weight PE. The extraction of the highly branched PE from the PE blend produced at $50{ }^{\circ} \mathrm{C}$ generated a "sandwich structure" (Figure 7b) similarly found for homogeneous binary catalyst system composed by $\left[\mathrm{NiCl}_{2}(\right.$ a-diimine $\left.)\right]$ and $\left[\mathrm{Tp}^{\mathrm{Ms}}{ }^{*} \mathrm{TiCl}_{3}\right]{ }^{9}$

\section{Conclusions}

We have shown that the combination of precursor catalysts $\mathbf{1}$ and $\mathbf{2}$ in the presence of MAO generates an effective binary catalyst system for ethylene polymerization. Different types of polyethylene blends can be produced depending on the 
a)

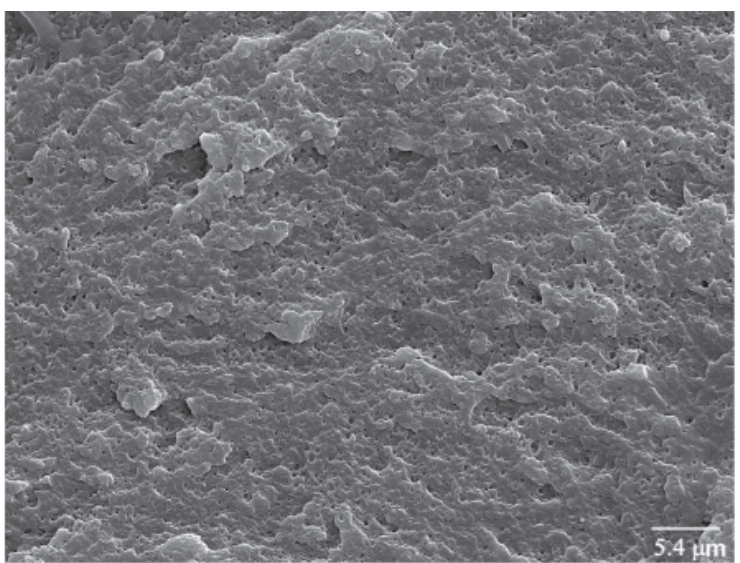

b)

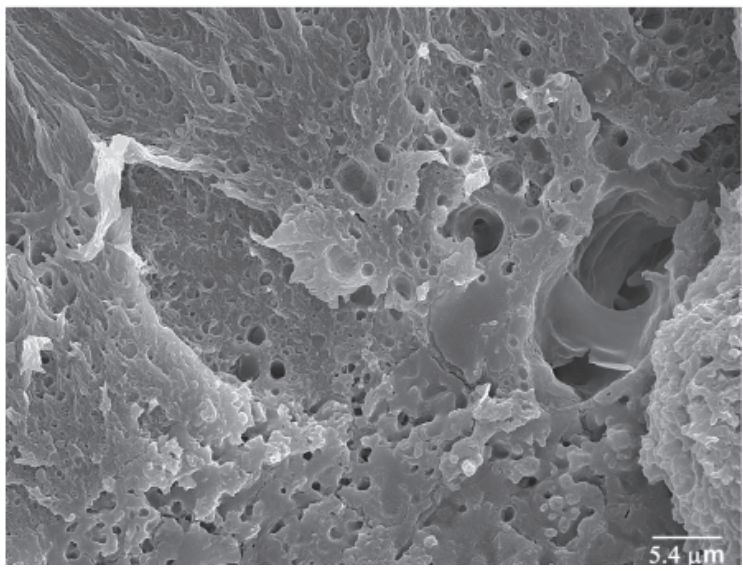

Figure 6. SEM micrographs of BPE/HDPE blends crio-fractured surfaces produced at $30{ }^{\circ} \mathrm{C}$ in hexane: (a) $\mathrm{x}_{\mathrm{Ni}}=0.25$ (x 2000); (b) $x_{\mathrm{Ni}}$ $=0.25$ (x 2000) after etching with $o$-xylene.

polymerization temperature, solvent, and $x_{\mathrm{Ni}}$. Higher activities have been found using toluene as solvent at $0{ }^{\circ} \mathrm{C}$ as a consequence of better stability of $\mathbf{1}$ at this polymerization conditions. The surface morphology of the blends revealed very low miscibility between the PE phases, resulting in the formation of big holes and defects distributed on the HDPE matrix. This behavior is associated mainly to the large difference of the PE properties produced by $\mathbf{1}$ and $\mathbf{2}$ that has led to spontaneous phase separation during ethylene polymerization carried out in hexane at $50{ }^{\circ} \mathrm{C}$.

\section{Acknowledgments}

We are grateful to the CNPq for the fellowships and CTPETRO-CNPq for financial support of this research. L. G. F. acknowledges CAPES (Brazil) for a fellowship.

\section{References}

1. Bochmann, M.; J. Chem. Soc. Dalton Trans. 1996, 255; Brintzinger, H. H.; Fischer, D.; Mülhaupt, R.; Rieger, B.; Waymouth, R. M.; Angew. Chem. Int. Ed. 1995, 34, 1143; a)

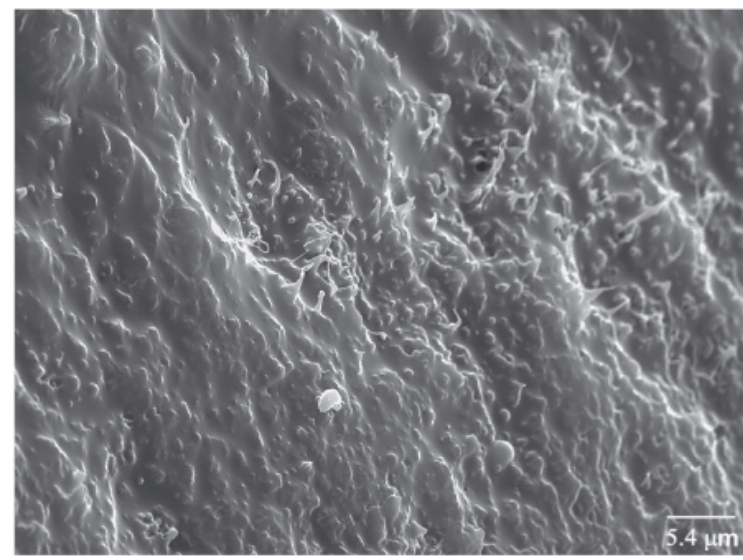

b)

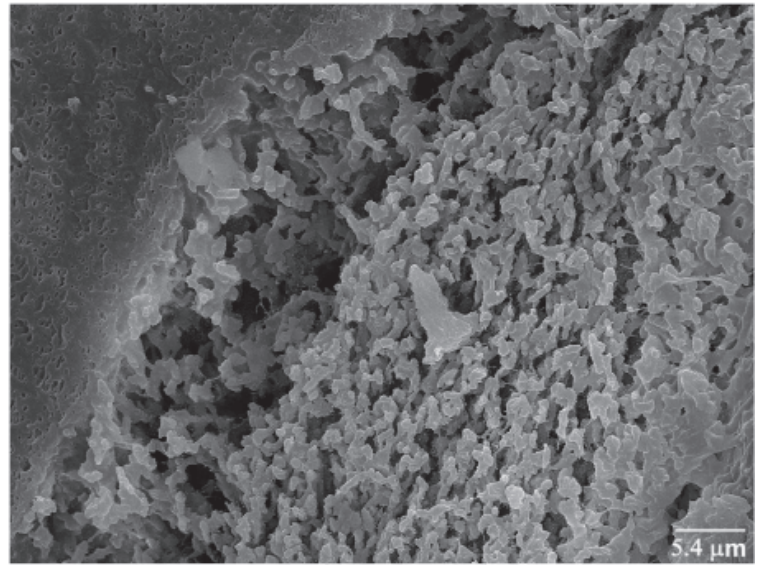

Figure 7. SEM micrographs of BPE/HDPE blends crio-fractured surfaces produced at $50{ }^{\circ} \mathrm{C}$ in hexane: (a) $\mathrm{x}_{\mathrm{Ni}}=0.25$; (b) $x_{\mathrm{Ni}}=0.25$ after etching with $o$-xylene.

McKnight, A. L.; Waymouth, R. M.; Chem Rev. 1998, 98, 2587; Alt, H. G.; Koppl, A.; Chem. Rev. 2000, 100, 1205; Gibson, V. C.; Spitzmesser, S. K.; Chem. Rev. 2003, 103, 283; Ittel, S. D.; Johnson, L. K.; Brookart, M.; Chem. Rev. 2000, $100,1169$.

2. Schuman, T.; Stepanov, E. V.; Nazarenko, S.; Capaccio, G.; Hiltner, A.; Baer, E.; Macromolecules 1998, 31, 4551; Wignall, G. D.; Alamo, R. G.; Londono, J. D.; Mandelkern, L.; Kim, M. H.; Lin, J. S.; Brown, G. M.; Macromolecules 2000, 33, 551; Agamalian, M.; Wignall, G. D.; Alamo, R. G.; Londono, J. D.; Kim, M. H.; Mandelkern, L.; Macromolecules 1999, 32, 3093.

3. Komon, Z. J. A.; Bazan, G. C.; Macromol. Rapid Commun. 2001, 22, 467; De Souza, R. F.; Casagrande Jr., O. L.; Macromol. Rapid Commun. 2001, 22, 1293; Sperber, O.; Kaminsky, W.; Macromolecules 2003, 36, 9014; Soares, J. B. P.; Kim, J. D.; J. Polym. Sci. Part A: Polym. Chem. 2000, 38, 1408; Soares, J. B. P.; Kim, J. D.; J. Polym. Sci. Part A: Polym. Chem. 2000, 38, 1417; Soares, J. B. P.; Beigzadeh, D.; Duever, T. A.; Da Silva Filho, A. A.; Polym. React. Eng. 2000, 8, 241; Markel, E. J.; Weng, W.; Peacock, A. J.; Dekmenziann, A. H.; Macromolecules 2000, 33, 8541. 
4. Komon, Z. J. A.; Bu, X.; Bazan, G. C.; J. Am. Chem. Soc. 2000, 122, 1830; Komon, Z .J. A.; Bu, X.; Bazan, G. C.; J. Am. Chem. Soc. 2000, 122, 12379; Abramo, G. P.; Li, L.; Marks, T. J.; J. Am. Chem. Soc. 2002, 124, 13966.

5. Komon, Z. J. A.; Diamond, G. M.; Leclerc, M. K.; Murphy, V.; Okazaki, M.; Bazan, G. C.; J. Am. Chem. Soc. 2002, 124, 15280; Quijada, R.; Rojas, R.; Bazan, G. C.; Komon, Z. J. A.; Mauler, R. S.; Galland, G. B.; Macromolecules 2001, 34, 2411.

6. Read, D. J.; Soares, J. B. P.; Macromolecules 2003, 36, 10037; Sperber, O.; Kaminsky, W.; Macromolecules 2003, 36, 9014; Iedema, P. D.; Hoefsloot, H. C. J.; Macromolecules 2003, 36 6632; Beigzadeh, D.; Soares, J. B. P.; Duever, T. A.; Macromol. Rapid Commun. 1999, 20, 541; Beigzadeh, D.; Soares, J. B. P.; Hamielec, A. E.; J. Appl. Polym. Sci. 1999, 71, 1753; Beigzadeh, D.; Soares, J. B. P.; Hamielec, A. E.; Polym. React. Eng. 1997, 5, 143; Soares, J. B. P.; Macromol. Theory Simul. 2002, 11, 184.

7. Bruaseth, I.; Rytter, E.; Macromolecules 2003, 36, 3026.

8. Mecking, S.; Macromol. Rapid Commun. 1999, 20, 139.

9. Kunrath, F. A.; De Souza, R. F.; Casagrande Jr., O. L.; Macromol. Rapid. Commun. 2000, 121, 277; Kunrath, F. A. Mauler, R. S.; De Souza, R. F.; Casagrande Jr., O. L.; Macromol. Chem Phys. 2002, 203, 2058; Mota, F. F.; de Souza, R. F.; Mauler, R. S.; Casagrande Jr., O. L.; Macromol. Chem Phys. 2001, 202, 1016; Mota, F. F.; De Souza, R. F.; Mauler, R. S.; Casagrande Jr., O. L.; Polymer 2003, 44, 4127; Junges, F.; Dos
Santos, J. H. Z.; De Souza, R. F.; Casagrande Jr., O. L.; Macromol. Mater. Eng. 2005, 290, 72.

10. Kunrath, F. A.; Furlan, L. G.; De Souza, R. F.; Casagrande Jr, O. L.; J. Mol. Catal. A: Chem. 2004, 214, 207.

11. $x_{\mathrm{Ni}}$ is defined as the nickel mole fraction calculated from $(\mathrm{Ni}) /((\mathrm{Ni})+(\mathrm{V}))$.

12. van Koten, G.; Vrieze, K. In Advances in Organometallic Chemistry; Stone, F. G. A.; West, R., eds.; Acad. Press: New York, 1982, vol. 21, p. 169.

13. Casagrande, A. C. A.; MSc. Dissertation, Universidade Federal do Rio Grande do Sul, Porto Alegre, Brazil, 2000.

14. Predicted activity $=$ (activity of catalyst $\mathbf{1} \times$ mole fraction of catalyst $\mathbf{1})+($ activity of catalyst $\mathbf{2}$ x mole fraction of catalyst $\mathbf{2}$ ).

15. Simon, L. C.; Mauler, R. S.; De Souza, R. F.; J. Polym. Sci. A: Polym. Chem. 1999, 37, 4656; Mota, F. F.; Kunrath, F. A.; De Souza, R. F.; Mauler, R. S.; Casagrande Jr., O. L.; Macromol. Chem Phys. 2002, 203, 2407.

16. Gates, D. P.; Svejda, S. A.; Onate, E.; Killian, C. M.; Johnson, L. K.; White, P. S.; Brookhart, M., Macromolecules 2000, 33, 2320; Simon, L. C.; Mauler, R. S.; de Souza, R. F.; J. Polym. Sci. Part A: Polym. Chem. 1999, 37, 4656.

17. Schleis, T.; Spaniol, T. P.; Okuda, J.; Heinemann, J.; Mülhaupt, R.; J. Organometal. Chem. 1998, 569, 159.

Received: January 12, 2005 Published on the web: October 6, 2005 